\title{
Congenital Mesoblastic Nephroma
}

National Cancer Institute

\section{Source}

National Cancer Institute. Congenital Mesoblastic Nephroma. NCI Thesaurus. Code C6569.

A low grade childhood congenital malignant neoplasm arising from the kidney. It is characterized by the presence of fibroblastic cells. The majority of cases occur in the first year of life. Complete excision is usually associated with an excellent prognosis. 